\title{
Microalgae Cultivation in Pilot Scale for Biomass Production Using Exhaust Gas from Thermal Power Plants
}

\author{
Sanghyun Park ${ }^{1,2} \mathbb{D}$, Yongtae Ahn ${ }^{1}$, Kalimuthu Pandi ${ }^{1}$, Min-Kyu Ji ${ }^{3}$, Hyun-Shik Yun ${ }^{4}$ \\ and Jae-Young Choi ${ }^{1, *}$ \\ 1 Center for Environment, Health and Welfare Research, Korea Institute of Science and Technology, \\ Seoul 02792, Korea; shsh1020@kist.re.kr (S.P.); ytahn@kist.re.kr (Y.A.); kpandi@kist.re.kr (K.P.) \\ 2 Graduate School of Energy and Environment (KU-KIST GREEN SCHOOL), Korea University, \\ Seoul 02841, Korea \\ 3 Environmental Assessment Group, Korea Environment Institute, Yeongi-gun 30147, Korea; mkji@kei.re.kr \\ 4 Dongmyung ent. Co., Ltd., Seoul 06254, Korea; awyhs81@gmail.com \\ * Correspondence: jchoi@kist.re.kr; Tel.: +82-2-958-5846
}

Received: 29 July 2019; Accepted: 9 September 2019; Published: 11 September 2019

\begin{abstract}
Exhaust gases from thermal power plants have the highest amount of carbon dioxide $\left(\mathrm{CO}_{2}\right)$, presenting an environmental problem related to a severe impact on ecosystems. Extensively, the reduction of $\mathrm{CO}_{2}$ from thermal power plants has been considered with the aid of microalgae as a cost-effective, sustainable solution, and efficient biological means for recycling of $\mathrm{CO}_{2}$. Microalgae can efficiently uptake $\mathrm{CO}_{2}$ and nutrients resulting in high generation of biomass and which can be processed into different valuable products. In this study, we have taken Nephroselmis sp. KGE8, Acutodesmus obliquus KGE 17 and Acutodesmus obliquus KGE32 microalgae, which are isolated from acid mine drainage and cultivated in a photobiological incubator on a batch scale, and also confirmed that continuous culture was possible on pilot scale for biofuel production. We also evaluated the continuous culture productivity of each cultivate-harvest cycle in the pilot scale. The biomass of the cultivated microalgae was also evaluated for its availability.
\end{abstract}

Keywords: biomass; microalgae; photobioreactor; power plant exhaust gas; lipid; FAME

\section{Introduction}

Nowadays, an increase of $\mathrm{CO}_{2}$ levels in the atmosphere is extensively recognized as a major contributor for global warming. Recent reports are highlighted that atmosphere contains $\mathrm{CO}_{2}$ level of $450 \mathrm{ppm}$ [1]. The atmospheric $\mathrm{CO}_{2}$ can be trapped by green plants via photosynthesis. However, terrestrial plants are estimated to reduce only 3-6\% of global $\mathrm{CO}_{2}$ emissions, which is significant given the slow growth rates of plants. On the other hand, microalgae can grow much faster than terrestrial plants, and their $\mathrm{CO}_{2}$ reduction efficacy was 10-50 times higher than plants [2,3]. The variety of microalgae cultivated in comfortable environmental condition to produce comparably 15-300 times higher energy sources than plants, which also reduce the land area for cultivation and continuously increase the yield per unit area $[2,4,5]$. Microalgae can biologically store $\mathrm{CO}_{2}$ through photosynthesis in the form organic compounds and then use microalgal biomass as a feedstock for renewable energy after $\mathrm{CO}_{2}$ fixation [6]. Moreover, microalgae have been documented as source of valuable biomaterials such as fertilizers, live feed, medicines, and other value-added products.

The large-scale microalgae culture system was divided into two systems, namely the open and closed systems. In the case of the open system, it is difficult to control the amount of light intensity and it may vary depend upon the local time, and also difficult to maintain the temperature. The closed 
system, which is a device to overcome these limitations, is able to control the light intensity, external influence, and temperature, though the operation cost and the manufacturing cost are high when compared to the open system. Especially, the closed system microalgal growth rate is 1.5-4 times higher than the open system [7]. The high growth rate of microalgae has a large impact on $\mathrm{CO}_{2}$ capture and may lead to an increase in biomass production. According to the various research condition, closed system may be designed as airlift column, horizontal tube, stirred tank, and flat panel photobioreactor (PBR) $[7,8]$.

Obviously, industrial exhaust gases contain $10-20 \%$ of $\mathrm{CO}_{2}$ with trace amounts of $\mathrm{SO}_{\mathrm{x}}$ and $\mathrm{NO}_{\mathrm{x}}$. The selection of microalgae plays a vital role in $\mathrm{CO}_{2}$ reduction efficacy and represents a significantly cost-effective route for biomass production. The desirable qualities of microalgae comprise high growth and $\mathrm{CO}_{2}$ consumption rates, also patience towards trace constituents of exhaust flue gases such as $\mathrm{SO}_{\mathrm{x}}$ and $\mathrm{NO}_{\mathrm{x}}$ and production of valuable products. Maeda et al. (1996) used Chlorella sp. T-1 as a potential microalga for the biological removal of exhausted $\mathrm{CO}_{2}$ from coal-fired thermal power plants. Aslam et al. (2017) have identified that mixed microalgae societies like Desmodesmus spp. can slowly grow in $100 \%$ unfiltered exhausted gas from coal combustion with phosphate buffering condition [9]. Kassim and Meng (2017) studied biofixation of $\mathrm{CO}_{2}$ by two microalgae species such as Chlorella sp. and Tetraselmis suecica with various $\mathrm{CO}_{2}$ concentration [10]. Even though the above said studies have been carried out in exhausted gas which adversely affects the microalgal growth. To the best of our knowledge, no study has yet reported on the actual injection of exhaust gas, and there is a lack of research on biomass tendency when continuously injecting the gas into large-scale bioreactor.

Hence, the objective of this study is to evaluate the feasibility of microalgae species like Nephroselmis sp. KGE8, Acutodesmus obliquus KGE 17 and Acutodesmus obliquus KGE32, which were cultivated in a laboratory with the supplementation of power plant exhaust gas. Then, evaluate the growth potential of the microalgae in the semi-continuous photobioreactor (PBR) operating with the exhaust gas injection, and evaluate the microalgae productivity at each cultivate-harvest cycle. Finally, we also assessed the feasibility of biodiesel, lipid and C16-18-FAME contents in recovered microalgae.

\section{Materials and Methods}

\subsection{Conditions of Microalgae Cultivation in Batch Scale}

Microalgae species were derived from acid mine drainage which include Nephroselmis sp. KGE8, Acutodesmus obliquus KGE 17, and Acutodesmus obliquus KGE32. The batch type cultivation was performed in $140 \mathrm{~mL}$ serum bottle with $100 \mathrm{~mL}$ of Bold's Basal Medium (BBM) [11] which contained strains with optical density of 0.010 in UV spectroscopy $680 \mathrm{~nm}$ region.

The exhaust gas from the Y coal-fired thermal power plant (Gangwon-do, South Korea) was used as a carbon source for microalgae growth. The collected gas was filtered through a $0.2 \mu \mathrm{m}$ filter and then supplied at a flow rate of $0.5 \mathrm{~L} \mathrm{~min}^{-1}$ for $1 \mathrm{~h}$ to complete saturation of the medium. Composition of the exhaust gas details appeared in Table 1 . The microalgae cultivation was conducted at $25{ }^{\circ} \mathrm{C}$ with $120 \mu \mathrm{mol}$ photon $\mathrm{m}^{-2} \mathrm{~s}^{-1}$ of light intensity, and the content was agitated in incubator shaker (Witeg, Wisecube WIS-ML, Germany) at $120 \mathrm{rpm}$ to prevent agglomeration for 7 days.

Table 1. Y Power plant gas contents and concentrations located in Gangwon-do.

\begin{tabular}{cc}
\hline Gas Contents & Initial Gas Concentration \\
\hline $\mathrm{CO}_{2}(v / v \%)$ & $14.9( \pm 0.2)$ \\
\hline $\mathrm{NO}_{\mathrm{x}}(\mathrm{ppmv})$ & $220.2( \pm 10.5)$ \\
\hline $\mathrm{SO}_{\mathrm{x}}(\mathrm{ppmv})$ & $32( \pm 5)$ \\
\hline $\mathrm{CO}(\mathrm{ppmv})$ & $1549( \pm 242)$ \\
\hline $\mathrm{O}_{2}(\%)$ & $5.47( \pm 0.03)$ \\
\hline
\end{tabular}




\subsection{Cultivation of Microalgae in Photobioreactor (PBR)}

The culture system used in this study was a multistage photobioreactor (PBR), each PBR has capacity of $2000 \mathrm{~L}$ and it is shown in Figure 1. Initially, exhausted gas was injected through PBR 1 and then subsequently passed through the PBR $2,-3$ and -4 respectively. Finally, unutilized gas was ejected from the PBR 5, the concentration of $\mathrm{CO}_{2}$ in each stage was measured and attached in Table 2. The initial and final exhaust gas concentration was analyzed by Testo $350 \mathrm{~K}$ emission analyzer (Testo, Germany). According to Blair et al. (2014) red light emitting diode (LED) was installed at each stage for maximize light absorption [12]. The first stage of the pilot scale, the growth rate of each stage of Nephroselmis sp. KGE 8 was determined and grown for 20 days. The second cultivation was performed for 22 days, from the 18 days when the specific growth rate $\left(\mu_{\max }\right)$ started to increase, the possibility of continuous cultivation was evaluated by harvest and regrowth. On day 18 , the microalgae were recovered and diluted and re-cultured for 16 days and supplemented with BBM to prevent nutrition loss. The interval between collection and incubation was 2 days, and cultures were collected and cultivated three times.

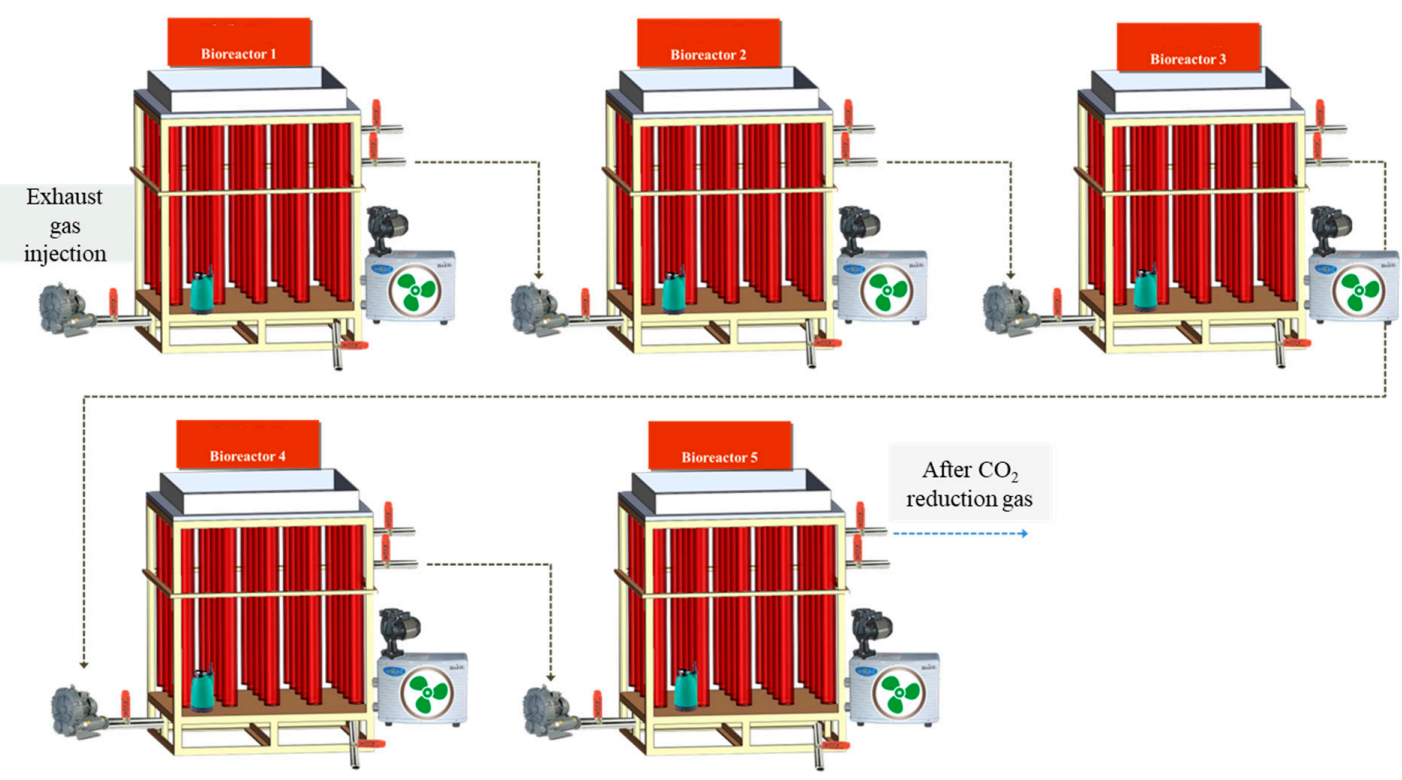

Figure 1. Pilot scale multi-step reactor schematic.

Table 2. Injection $\mathrm{CO}_{2}$ concentration in each stage.

\begin{tabular}{ccccc}
\hline Stage & $\mathrm{CO}_{2}(v / v \%)$ & $\mathrm{NO}_{\mathbf{x}}(\mathrm{ppmv})$ & $\mathrm{CO}(\mathrm{ppmv})$ & $\mathrm{O}_{2}(v / v \%)$ \\
\hline PBR1 & $14.90( \pm 0.18)$ & $220.2( \pm 10.5)$ & $1548.5( \pm 242)$ & $5.47( \pm 0.03)$ \\
\hline PBR2 & $8.08( \pm 0.52)$ & $124.4( \pm 21.8)$ & $941.1( \pm 41.9)$ & $12.42( \pm 0.93)$ \\
\hline PBR3 & $6.72( \pm 0.73)$ & $99.3( \pm 16.0)$ & $703.3( \pm 51.4))$ & $13.89( \pm 0.99)$ \\
\hline PBR4 & $4.99( \pm 0.52)$ & $72.3( \pm 12.1)$ & $537.2( \pm 21.6)$ & $15.81( \pm 0.86)$ \\
\hline PBR5 & $3.87( \pm 0.52)$ & $51.9( \pm 9.3)$ & $421.1( \pm 35.2)$ & $17.03( \pm 0.95)$ \\
\hline Out & $3.11( \pm 0.60)$ & $51.8( \pm 8.18)$ & $337.0( \pm 5.1)$ & $16.86( \pm 1.41)$ \\
\hline
\end{tabular}

\subsection{Analysis of Microalgal Growth}

The growth rate of microalgae cultivated in pilot plant was obtained by analysis of $\mathrm{OD}_{680}$, from spectrophotometer (Hach DR/2800, Loveland, CO, USA) which values were converted to dry cell weight (DCW) concentration $\left(\mathrm{g} \mathrm{L}^{-1}\right)$. DCW of Nephroselmis sp. KGE 8 was calculated by:

$$
\text { Dry weight }\left(\mathrm{g} \mathrm{L}^{-1}\right)=0.3997 \times \mathrm{OD}_{680}-0.0471\left(\mathrm{R}^{2}=0.9871\right)
$$


Further, the specific growth rate (SGR) was calculated by Equation (2):

$$
\mu=\left(\ln X_{2}-\ln X_{1}\right) /\left(t_{2}-t_{1}\right)
$$

where $X_{1}$ and $X_{2}$ are the mass of initial and final weight of microalgae, respectively, which is used to calculate DCW in this study, and $t_{1}$ and $t_{2}$ are the initial and final incubation times respectively.

\subsection{Algal Harvest}

In pilot scale, the algal harvest was performed by sludge pump, and collected to storage tank. The algae of each stage were harvested, and the harvested algae were precipitated and recovered by separating the supernatant and algae.

\subsection{Analysis of Lipid and C16-C18 Fatty Acid Methyl Ester (FAME)}

The modified Bilgh and Dyer method (Ji et al. (2016)) was used to analyze the lipids and fatty acids in the harvested microalgae [13]. Fatty acids were identified by the modified Lepage and Roy method from Yun et al. (2015), which convert fatty acid into fatty acid methyl esters through esterification and is analyzed by Gas chromatography with a flame ionization detector (GC-FID) using HP-INNOWax capillary column (Agilent Technologies, USA) [14].

\section{Results and Discussion}

\subsection{Growable Microalgae in Exhaust Gas Condition}

Batch scale experiment results shows that both Nephroselmis sp. KGE 8 and Acutodesmus obliquus KGE 17 have lag phase up to two days and showed exponential growth phase until fifth day (Figure 2). At this moment, Nephroselmis sp. KGE 8 exhibited the maximum growth when compared to the Acutodesmus obliquus KGE 17. Another microalga like Acutodesmus obliquus KGE 32 exhibits the lag phase until three days, and the exponential growth phase was until five days, and it has the stationary growth phase. The growth rates of microalgae with a supply of exhaust gas are presented in Table 3 . Ji et al. (2017) and Yun et al. (2016) evaluated the potential for biofuel production according to changes of $\mathrm{CO}_{2}$ concentration in exhaust gas. Compare with these previous studies, algae production was faster. Also Tang et al. (2011) was focused on growth potential in high concentration of $\mathrm{CO}_{2}$ and effective concentration of $\mathrm{CO}_{2}$, growth rate and lipid contents was lower than this study. Nephroselmis sp. KGE 8 have the $\mathrm{OD}_{680}$ value of 1.341 and the maximum specific growth rate $\left(\mu_{\max }\right)$ was $1.41 \mathrm{~d}^{-1}$ between $3-4$ days of culture. Conversely, Acutodesmus obliquus KGE 32 and Acutodesmus obliquus KGE 17 possess the $\mathrm{OD}_{680}$ values of 0.970 and 0.553 and $\mu_{\max }$ were $1.08 \mathrm{~d}^{-1}$ and $1.37 \mathrm{~d}^{-1}$ respectively. The microalgae, which applied in this study, showed higher specific grow rates $\left(1.08\right.$ to $\left.1.37 \mathrm{~d}^{-1}\right)$ than previous study (Table 3). Continuous and excessive exposure of $\mathrm{NO}_{\mathrm{x}}$ and $\mathrm{SO}_{\mathrm{x}}$ gases to cells could leads to inhibition of microalgae growth rate $[15,16]$. Praveenkumar et al. (2014a) reported that algal FAME content and productivity increased from 129 to $168 \mathrm{mg}$ fame/g cells and from 59 to $118 \mathrm{mg}$ fame/L d, respectively, in coal-fired flue-gas inlet condition [17]. They also conclude that stress conditions could lead to improve algal lipid productivity [18].

\subsection{Pilot Scale Cultivation}

The pilot scale cultivation result discloses that, lag phase period of Nephroselmis sp. KGE 8 was increased from 2 days to 10 days when compared with batch scale results due to the stress present in the exhaust gas (Figure 3). Same trend was also observed in previous study by Borowitzka et al. (2018) and mentioned that adaptation by stress due to $\mathrm{CO}_{2}[21]$. 


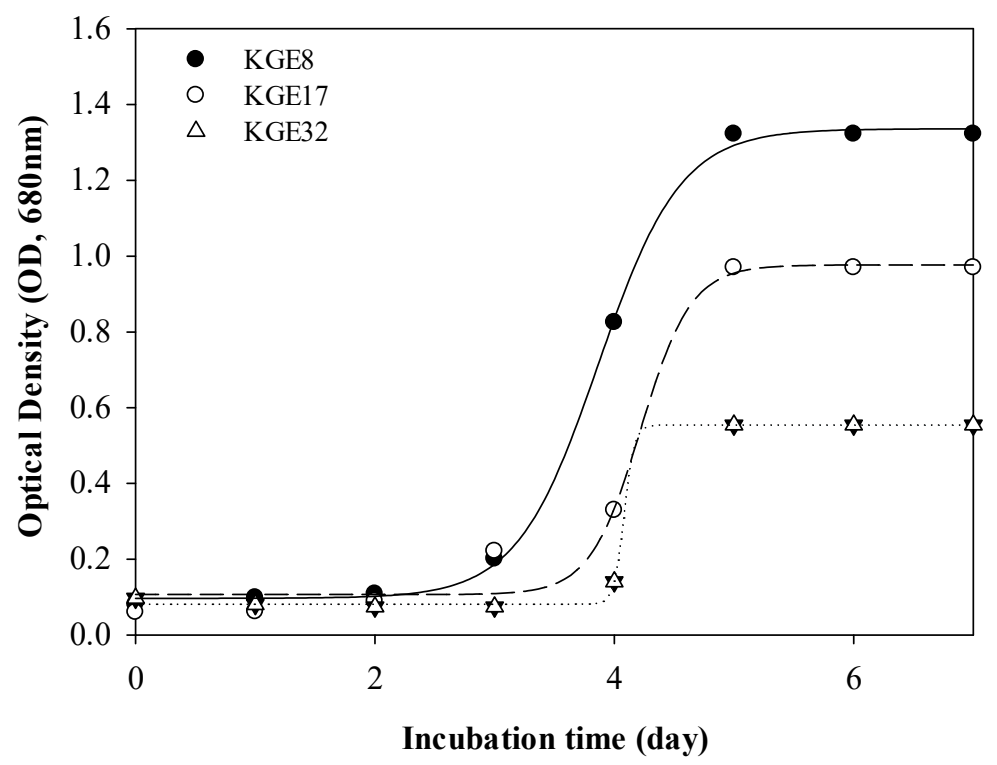

Figure 2. Growth curve of Nephroselmis sp. KGE 8, Acutodesmus obliquus KGE 17, and Acutodesmus obliquus KGE 30 microalgae in purged power plant gas.

Table 3. Specific growth rate and lipid contents of various microalgal strains cultivated at different carbon dioxide concentration.

\begin{tabular}{|c|c|c|c|c|c|}
\hline Species & $\begin{array}{c}\text { Carbon Dioxide } \\
\text { Concentration (\%) }\end{array}$ & $\begin{array}{l}\text { Incubation } \\
\text { Condition }\end{array}$ & Medium & $\begin{array}{c}\text { Lipid } \\
\text { Contents (\%) }\end{array}$ & $\begin{array}{c}\text { Specific } \\
\text { Growth Rate } \\
\left(\mu_{\max }, d^{-1}\right)\end{array}$ \\
\hline Scenedesmus obliquus KGE $9^{\text {a }}$ & 14.1 & Batch & BBM & 22.8 & 1.00 \\
\hline Chlorella pyrenoidosa SJTU-2 b & 10.0 & Batch & BG11 & 24.2 & 0.78 \\
\hline Acutodesmus obliquus KGE $30^{c}$ & 14.1 & Batch & BBM & 17.5 & 1.09 \\
\hline Acutodesmus obliquus KGE $32^{\mathrm{d}}$ & 14.1 & Batch & BBM & - & 1.08 \\
\hline Acutodesmus obliquus KGE $17^{\mathrm{d}}$ & 14.1 & Batch & BBM & - & 1.37 \\
\hline Nephroselmis sp. KGE 8 d & 14.1 & Batch & BBM & 59.4 & 1.41 \\
\hline 0 Nephroselmis $s p$. KGE $8^{\mathrm{d}}$ & 14.1 & Pilot scale & BBM & 60.9 & 0.26 \\
\hline
\end{tabular}

Further, the microalgae growth was not similar with the batch scale (Figure 3). Due to the different character of coal and also the generated exhaust gas from the thermal power plant does not contain constant amount of $\mathrm{CO}_{2}$, it may lead to irregular growth of microalgae in the pilot scale. Cheng et al. (2019) also reported that biomass yields were not constant for every cycle, even gas-adapted microalgae were injected with a constant concentration of mixed gas [22]. These results indicated that Nephroselmis KGE 8 is a microalga species that could adaptively grow, even when the exhaust gas was continuously injected.

In continuous culture potential evaluation experiment, Nephroselmis sp. KGE 8 reached the exponential growth phase at 17 days after initiated the cultivation (Figure 4). According to Tan et al. (2018), the productivity of microalgae tended to decrease with increasing amount of cultivation [23]. The growth of Nephroselmis sp. KGE 8 was different in each stage. PBR 2 show a microalgae concentration of $0.6002 \mathrm{~g} \mathrm{~L}^{-1}$ for the first time and $0.4932 \mathrm{~g} \mathrm{~L}^{-1}$ for the second cultivation. Also the microalgae concentration in PBR 3, PBR 4, and PBR 5 was decreased from $0.5644 \mathrm{~g} \mathrm{~L}^{-1}$ to $0.4955 \mathrm{~g} \mathrm{~L}^{-1}, 0.5343 \mathrm{~g} \mathrm{~L}^{-1}$ to $0.4722 \mathrm{~g} \mathrm{~L}^{-1}$, and $0.4421 \mathrm{~g} \mathrm{~L}^{-1}$ to $0.4116 \mathrm{~g} \mathrm{~L}^{-1}$ respectively. In contrast, the microalgae growth in PBR 1 has increased from $0.4996 \mathrm{~g} \mathrm{~L}^{-1}$ to $0.5710 \mathrm{~g} \mathrm{~L}^{-1}$, unlike other stages. Biomass productivity is affected by growth factors, and according to Sun et al. (2018), the growth 
factors like high temperature and large $\mathrm{N}$ source will increase biomass growth [24]. When $\mathrm{NO}_{\mathrm{x}}$ is dissolved in water, it tends to form nitrite, which can help to grow the biomass [25].
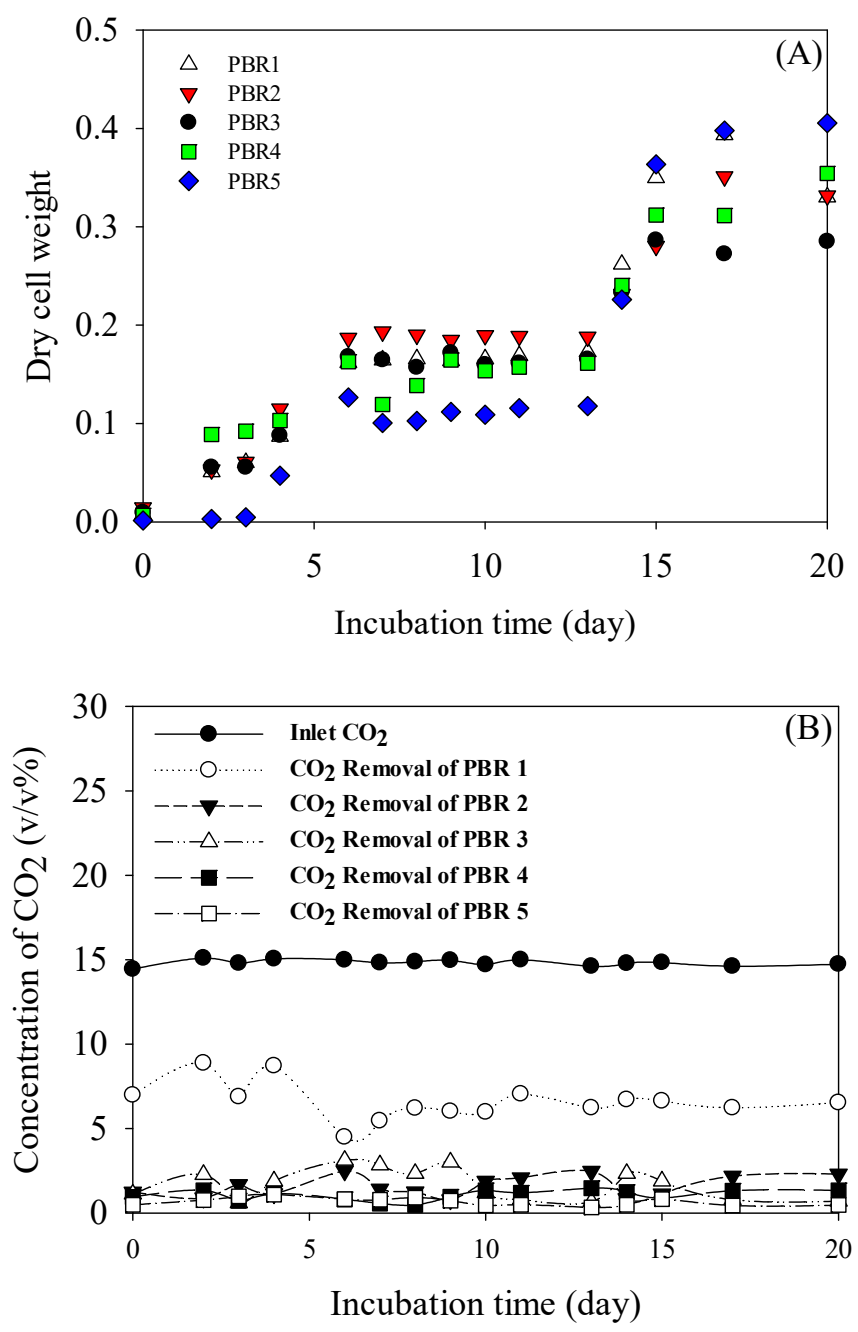

Figure 3. The growth of Neproselmis sp. KGE 8 when injecting exhaust gas from thermal power plant using multi-step reactor. Growth rate was shown to (A), and removal $\mathrm{CO}_{2}$ concentration was shown to (B).

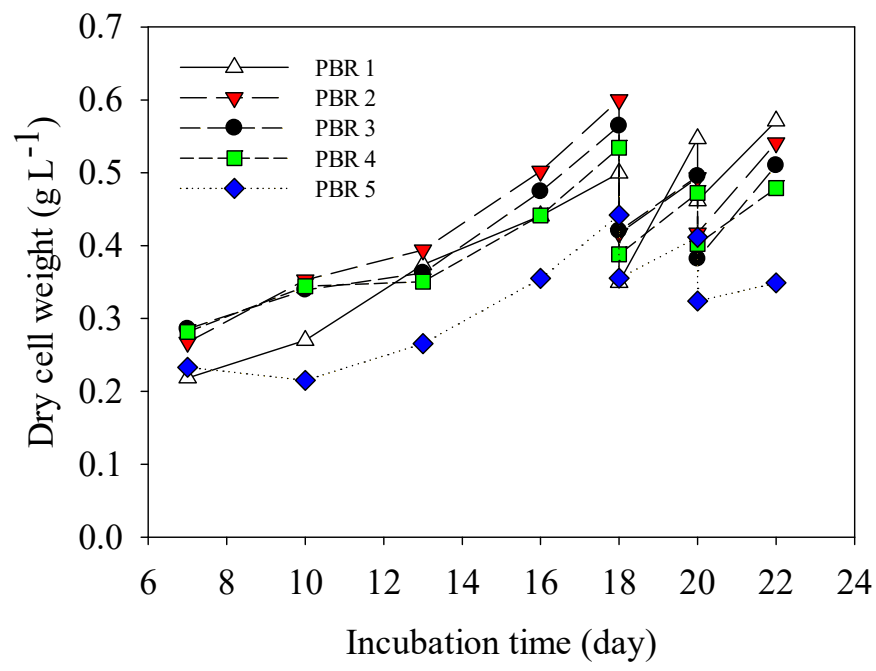

Figure 4. Microalgae growth curve in each incubator re-cultivation process. 


\subsection{Lipid and Fatty Acid Productivity}

We have compared the biomass productivity of Nephroselmis sp. KGE 8 in both batch and pilot scale. In batch scale, the biomass productivity was found to be $0.696 \mathrm{~g} \mathrm{~L}^{-1} \mathrm{~d}^{-1}$, also contain $59.4 \%$ and $95.1 \%$ of lipid and C16-C18 FAME respectively. In contrast, the biomass productivity, lipid, and C16-C18 FAME contents were decreased to $0.163 \mathrm{~g} \mathrm{~L}^{-1} \mathrm{~d}^{-1}, 39.4 \%$, and $77.8 \%$ respectively in pilot scale experiments (Table 4). Park et al. (2013) reported that the maximum lipid content of the Nephroselmis sp. KGE 8 species was $38.8 \%$ [26].

Table 4. Biomass productivity, C16-C18 ratio, and lipid content of Nephroselmis sp. KGE8 at laboratory scale and pilot scale.

\begin{tabular}{lccc}
\hline \multicolumn{1}{c}{ Strain } & $\begin{array}{c}\text { Volumetric Productivity of } \\
\text { Biomass at } \boldsymbol{\mu}_{\max }\left(\mathbf{g ~ L}^{-\mathbf{1}} \mathbf{d a y}^{-\mathbf{1}}\right)\end{array}$ & C16-C18 Ratio (wt \%) & Lipid Content (wt \%) \\
\hline KGE8 cultivated in Laboratory & 0.696 & 95.1 & 59.4 \\
\hline KGE8 Cultivated in Pilot scale & 0.163 & 77.8 & 60.9 \\
\hline
\end{tabular}

The average lipid content of harvested microalgae in PBR 1 was $41.24 \%$, which was higher than that of other stages. Arief et al. (2009) reported that the content of lipid in microalgae increased with increasing $\mathrm{CO}_{2}$ concentration. The fatty acid content of the recovered Nephroselmis sp. KGE 8 illustrated in Figure 5. The average of C16 to C18 FAME contents in recovered microalgae at each harvest cycle illustrated Figure 5A. The fatty acid content was $74.38 \%(w / w)$, and the highest fatty acid content showed the highest fatty acid content as $87.29 \%$ in PBR 5. However, as the number of continuous cultures increased, the fatty acid content of PBR 1 also increased, while that of PBR 2 to PBR 5 tended to decrease (Figure 5B). In particular, PBR 5, which showed the highest fatty acid content at the initial stage, showed a sharp decrease in fatty acid content as the number of times increased. Sharmaet al. (2012), and Nayaket al. (2018) reported an increase in Oleic acid (C18: 1) in the fatty acids of cultured algae in coal combustion gases $[27,28]$.

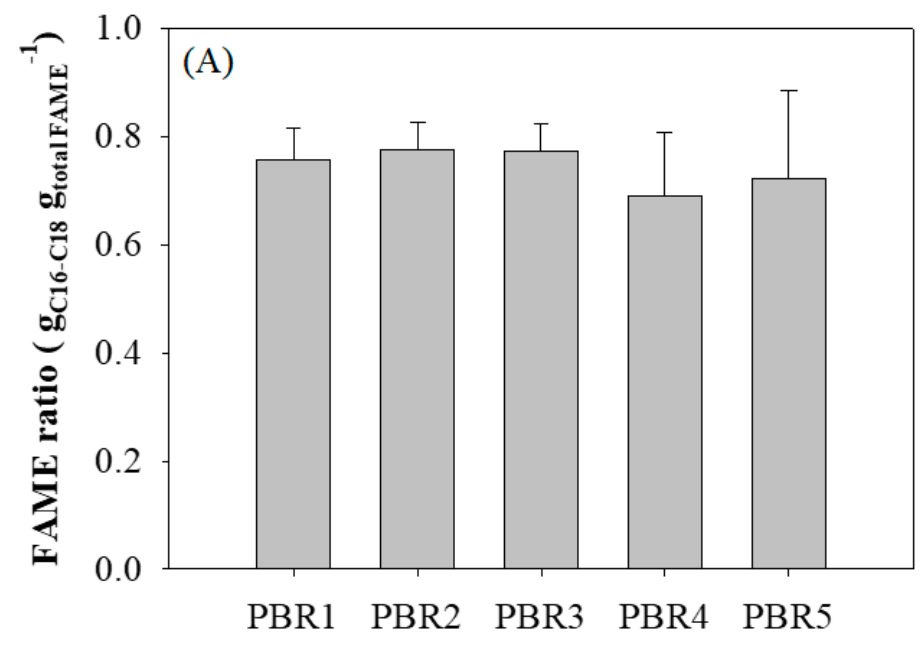

Figure 5. Cont. 


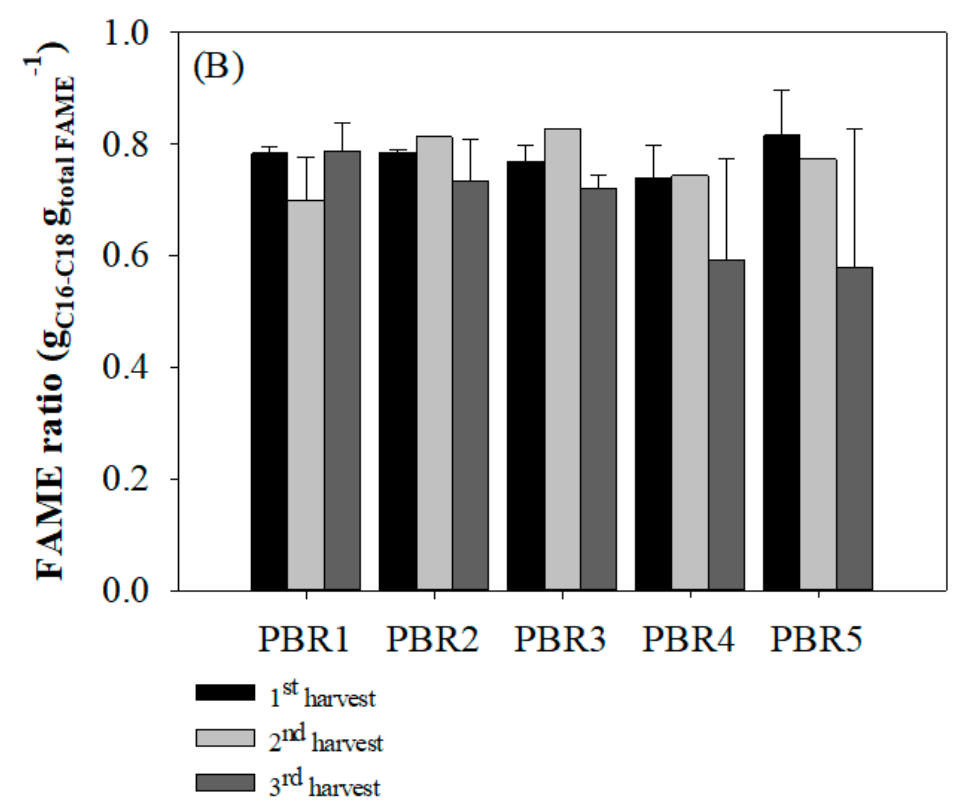

Figure 5. C16-C18 FAME yield from each photo bioreactor.

\section{Conclusions}

Batch scale studies reveal that Nephroselmis sp. KGE 8 showed the best growth under exhaust gas conditions. Nephroselmis sp. KGE 8 showed growth potential $\left(0.696 \mathrm{~g} \mathrm{~L}^{-1}\right)$ in the semi-continuous PBR operation with the exhaust gas injection. The lipid content and C16-C18 FAME content were $39.4 \%$ and $77.8 \%$ in PBR1, respectively. The microalgae productivity of five reactors showed range from $0.4116 \mathrm{~g}$ $\mathrm{L}^{-1}$ to $0.5468 \mathrm{~g} \mathrm{~L}^{-1}$ at each cultivate-harvest cycles. PBR 1 showed highest microalgae productivity during PBR operation.

When exhaust gas is directly injected, changes in $\mathrm{NO}_{\mathrm{x}}$ and temperature condition accelerate the microbial energy conversion. Singh et al. (2014) reported that some algal species obtained maximum biomass in $15 \% \mathrm{CO}_{2}$ [29]. Based on the result, it was concluded that direct injection of exhaust gas is the most suitable condition for utilization of energy source of microalgae. This microalgal cultivation system could be a suitable process for the massive cultivation of microalgae with exhaust gas from power plants.

Author Contributions: For research articles with several authors, a short paragraph specifying their individual contributions must be provided. The following statements should be used "Conceptualization, S.P. and H.-S.Y.; Methodology, H.-S.Y.; Software, S.P.; Validation, H.-S.Y.; Investigation, M.-K.J.; Data Curation, S.P.; Writing-Original Draft Preparation, S.P.; Writing-Review \& Editing, Y.A. and K.P.; Visualization, H.-S.Y.; Supervision, J.-Y.C.; Project Administration, J.-Y.C.; Funding Acquisition, J.-Y.C.".

Funding: This work was supported by the Korea CCS R\&D Center (Korea CCS 2020 Project) grant funded by the Korea government (Ministry of Science, ICT \& Future Planning) in 2019 (KCRC-2014M1A8A1049293) and the KIST Institutional Program (Project No. 2E29670).

Conflicts of Interest: The authors declare no conflict of interest.

\section{References}

1. Shen, Y. Carbon dioxide bio-fixation and wastewater treatment via algae photochemical synthesis for biofuels production. RSC Adv. 2014, 4, 49672-49722. [CrossRef]

2. Yuan, C.; Wang, S.; Cao, B.; Hu, Y.; Abomohra, A.E.-F.; Wang, Q.; Qian, L.; Liu, L.; Liu, X.; He, Z.; et al. Optimization of hydrothermal co-liquefaction of seaweeds with lignocellulosic biomass: Merging 2nd and 3rd generation feedstocks for enhanced bio-oil production. Energy 2019, 173, 413-422. [CrossRef] 
3. Cuellar-Bermudez, S.P.; Garcia-Perez, J.S.; Rittmann, B.E.; Parra-Saldívar, R. Photosynthetic bioenergy utilizing $\mathrm{CO}_{2}$ : An approach on flue gases utilization for third generation biofuels. J. Clean. Prod. 2015, 98, 53-65. [CrossRef]

4. Chisti, Y. Biodiesel from microalgae. Biotechnol. Adv. 2007, 25, 294-306. [CrossRef]

5. Yun, H. Carbon Dioxide Sequestration of Exhaust Fumes by Freshwater Microalgae with Massive Biomass Production. Bachelor's Thesis, Yonsei University, Seoul, Korea, 2015.

6. Zhao, B.; Su, Y.; Zhang, Y.; Cui, G. Carbon dioxide fixation and biomass production from combustion flue gas using energy microalgae. Energy 2015, 89, 347-357. [CrossRef]

7. Chew, K.W.; Chia, S.R.; Show, P.L.; Yap, Y.J.; Ling, T.C.; Chang, J.-S. Effects of water culture medium, cultivation systems and growth modes for microalgae cultivation: A review. J. Taiwan Inst. Chem. Eng. 2018, 91, 332-344. [CrossRef]

8. Zhao, B.; Su, Y. Process effect of microalgal-carbon dioxide fixation and biomass production: A review. Renew. Sustain. Energy Rev. 2014, 31, 121-132. [CrossRef]

9. Aslam, A.; Thomas-Hall, S.R.; Mughal, T.A.; Schenk, P.M. Selection and adaptation of microalgae to growth in 100\% unfiltered coal-fired flue gas. Bioresour. Technol. 2017, 233, 271-283. [CrossRef]

10. Kassim, M.A.; Meng, T.K. Carbon dioxide $\left(\mathrm{CO}_{2}\right)$ biofixation by microalgae and its potential for biorefinery and biofuel production. Sci. Total Environ. 2017, 584, 1121-1129. [CrossRef]

11. Bischoff, H.W. Phycological studies. IV. Some Algae from Enchanted Rock and Related Algal Species. Univ. Texas Publ. 1963, 6318, 95.

12. Blair, M.F.; Kokabian, B.; Gude, V.G. Light and growth medium effect on Chlorella vulgaris biomass production. J. Environ. Chem. Eng. 2014, 2, 665-674. [CrossRef]

13. Ji, M.-K.; Yun, H.-S.; Hwang, B.S.; Kabra, A.N.; Jeon, B.-H.; Choi, J. Mixotrophic cultivation of Nephroselmis sp. using industrial wastewater for enhanced microalgal biomass production. Ecol. Eng. 2016, 95, 527-533. [CrossRef]

14. Yun, H.S.; Ji, M.K.; Park, Y.T.; Salama el, S.; Choi, J. Microalga, Acutodesmus obliquus KGE 30 as a potential candidate for $\mathrm{CO}_{2}$ mitigation and biodiesel production. Environ. Sci. Pollut. Res. Int. 2016, 23, 17831-17839. [CrossRef] [PubMed]

15. Li, Y.; Horsman, M.; Wang, B.; Wu, N.; Lan, C.Q. Effects of nitrogen sources on cell growth and lipid accumulation of green alga Neochloris oleoabundans. Appl. Microbiol. Biotechnol. 2008, 81, 629-636. [CrossRef] [PubMed]

16. Chiu, S.-Y.; Kao, C.-Y.; Huang, T.-T.; Lin, C.-J.; Ong, S.-C.; Chen, C.-D.; Chang, J.-S.; Lin, C.-S. Microalgal biomass production and on-site bioremediation of carbon dioxide, nitrogen oxide and sulfur dioxide from flue gas using Chlorella sp. cultures. Bioresour. Technol. 2011, 102, 9135-9142. [CrossRef] [PubMed]

17. Praveenkumar, R.; Kim, B.; Choi, E.; Lee, K.; Cho, S.; Hyun, J.-S.; Park, J.-Y.; Lee, Y.-C.; Lee, H.U.; Lee, J.-S.; et al. Mixotrophic cultivation of oleaginous Chlorella sp. KR-1 mediated by actual coal-fired flue gas for biodiesel production. Bioprocess Biosyst. Eng. 2014, 37, 2083-2094. [CrossRef] [PubMed]

18. Praveenkumar, R.; Kim, B.; Choi, E.; Lee, K.; Park, J.-Y.; Lee, J.-S.; Lee, Y.-C.; Oh, Y.-K. Improved biomass and lipid production in a mixotrophic culture of Chlorella sp. KR-1 with addition of coal-fired flue-gas. Bioresour. Technol. 2014, 171, 500-505. [CrossRef] [PubMed]

19. Ji, M.K.; Yun, H.S.; Hwang, J.H.; Salama, E.S.; Jeon, B.H.; Choi, J. Effect of flue gas $\mathrm{CO}_{2}$ on the growth, carbohydrate and fatty acid composition of a green microalga Scenedesmus obliquus for biofuel production. Environ. Technol. 2017, 38, 2085-2092. [CrossRef]

20. Tang, D.; Han, W.; Li, P.; Miao, X.; Zhong, J.-J. CO $\mathrm{CO}_{2}$ biofixation and fatty acid composition of Scenedesmus obliquus and Chlorella pyrenoidosa in response to different $\mathrm{CO}_{2}$ levels. Bioresour. Technol. 2011, 102, 3071-3076. [CrossRef]

21. Borowitzka, M.A. The 'stress' concept in microalgal biology-Homeostasis, acclimation and adaptation. Environ. Boil. Fishes 2018, 30, 2815-2825. [CrossRef]

22. Cheng, D.; Li, X.; Yuan, Y.; Yang, C.; Tang, T.; Zhao, Q.; Sun, Y. Adaptive evolution and carbon dioxide fixation of Chlorella sp. in simulated flue gas. Sci. Total Environ. 2019, 650, 2931-2938. [CrossRef] [PubMed]

23. Tan, X.B.; Lam, M.K.; Uemura, Y.; Lim, J.W.; Wong, C.Y.; Ramli, A.; Kiew, P.L.; Lee, K.T. Semi-continuous cultivation of Chlorella vulgaris using chicken compost as nutrients source: Growth optimization study and fatty acid composition analysis. Energy Convers. Manag. 2018, 164, 363-373. [CrossRef] 
24. Sun, X.-M.; Ren, L.-J.; Zhao, Q.-Y.; Ji, X.-J.; Huang, H. Microalgae for the production of lipid and carotenoids: A review with focus on stress regulation and adaptation. Biotechnol. Biofuels 2018, 11, 272. [CrossRef] [PubMed]

25. Brown, L.M. Uptake of carbon dioxide from flue gas by microalgae. Energy Convers. Manag. 1996, 37, 1363-1367. [CrossRef]

26. Park, Y.-T.; Lee, H.; Yun, H.-S.; Song, K.-G.; Yeom, S.-H.; Choi, J. Removal of metal from acid mine drainage using a hybrid system including a pipes inserted microalgae reactor. Bioresour. Technol. 2013, 150, 242-248. [CrossRef] [PubMed]

27. Sharma, K.K.; Schuhmann, H.; Schenk, P.M. High Lipid Induction in Microalgae for Biodiesel Production. Energies 2012, 5, 1532-1553. [CrossRef]

28. Nayak, M.; Dhanarajan, G.; Dineshkumar, R.; Sen, R. Artificial intelligence driven process optimization for cleaner production of biomass with co-valorization of wastewater and flue gas in an algal biorefinery. J. Clean. Prod. 2018, 201, 1092-1100. [CrossRef]

29. Singh, S.; Singh, P. Effect of $\mathrm{CO}_{2}$ concentration on algal growth: A review. Renew. Sustain. Energy Rev. 2014, 38, 172-179. [CrossRef]

(C) 2019 by the authors. Licensee MDPI, Basel, Switzerland. This article is an open access article distributed under the terms and conditions of the Creative Commons Attribution (CC BY) license (http://creativecommons.org/licenses/by/4.0/). 